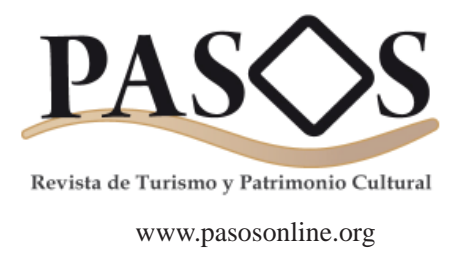

https://doi.org/10.25145/j.pasos.2012.10.022

Vol. 10 No 2. Special Issue. Pp. 3-16. 2012

\title{
Attainment of MDGs through tourism in the Central African sub-region: Implications for local economic development in Cameroon
}

\author{
Albert N. Kimbu ${ }^{i}$ \\ University of Surrey (United Kingdom)
}

\begin{abstract}
This paper examines the role and contribution of tourism to local economic development and in the attainment of the Millennium Development Goals one and seven dealing with extreme poverty alleviation and environmental sustainability in the biodiversity endowed Central African sub-region. The concepts of sustainable tourism development and local economic development (in sub-Saharan Africa) are examined. Through field observations and semi-structured interviews with 21 tourism industry stakeholders in Cameroon, an analysis of tourism's role and future in LED and in the attainment of the Millennium Development Goals 1 \& 7 is undertaken. The core challenges presently inhibiting tourism's development thereby limiting its contribution to local economic development and the attainment of these goals in Cameroon are identified and a framework within which tourism's contribution can be increased is proposed.
\end{abstract}

Keywords: Cameroon, Central Africa; Local economic development; Poverty alleviation; Environmen-tal conservation, Sustainable tourism.

Título: Logro de los ODM a través del turismo en la sub-región de Africa Central: Implicaciones para el desarrollo economic local de Camerún

Resumen: Este artículo examina el papel y la contribución del turismo al desarrollo económico local y en persecución de los Objetivos de Desarrollo del Milenio uno y siete referentes a la mitigación de la probreza extrama y la sostenibilidad ambiental en la biodiversa región de Africa Central. Los conceptos de desarrollo sostenible del turismo y desarrollo económico local (en le África subsahariana) son exami-nados. A través de observaciones de campo y entrevistas semi-estructuradas con 21 partes interesadas de la industria turística de Camerún, se lleva a cabo un análisis del papel y del futuro del turismo en el desarrollo económico local y del logro de los Objetivos de Desarrollo del Milenio 1 y 7. Los actuales desafíos que inhiben el desarrollo turístico limitando su contribución al desarrollo económico y local son identificados y un marco dentro del cual el turismo puede contribuir es propuesto.

Palabras clave: Camerún; África Central; Desarrollo económico local; Alivio de la pobreza; Conserva-ción del medio ambiente; Turismo sostenible.

i School of Hospitality and Tourism Management, University of Surrey, a.kimbu@surrey.ac.uk. 


\section{Introduction}

The sustainable development and use of tourism and environmental resources to promote local economic development (LED) and help in the eradication of extreme poverty and hunger, especially in developing countries, was one of the tools proposed by the UNEP in September 2000 when the Millennium Development Goals (MDG) were adopted in New York (UNDP, 2011). Two thirds of the way through, some developing countries in sub-Saharan Africa (SSA) such as Botswana, Gabon, Mauritius, the Seychelles have realised the importance of tourism as an important tool for local economic development and the attainment of some of the MDGs (especially goals 1 and 7), and successfully invested in its development (Botswana Tourist Board, 2007, Gabontour, 2010). Others, especially those in the Central African sub-region, despite recognising its importance have not given it the necessary attention it deserves. As a result, tourism's impact as a motor for local economic development still has to be felt. However, substantial efforts have theoretically been made by many governments of the sub-region, especially in Cameroon and Gabon, to increase the levels of environmental protection. Thus, the attainment of the above mentioned goals through tourism is rather mitigated. While discussing some of the theories of sustainable tourism development in relation to local economic development in SSA, this paper examines the issues that have contributed in making the achievement of the MDGs of poverty eradication/alleviation and environmental sustainability through tourism still a distant reality in Cameroon.

\section{Research aim}

Cameroon has been an island of relative peace and tranquillity in a region where political instability seems to be the order of the day (BBC, 2010). This, coupled with its triple colonial heritage (German, French and English), natural and cultural biodiversity, are key ingredients which if well utilised give it an added advantage of developing a successful tourism industry which could go a long way to attaining the MDGs of poverty alleviation and environmental conservation and sustainability thereby promoting LED. However, since the adoption of these goals, the use of tourism to achieve objectives 1 and 8 has been mitigated in Cameroon.

The main aim of this paper is to find out if and how successful tourism has been, and how it is contributing to attaining these goals and therefore LED with just 5 years to go, in spite of the country's abundant natural and cultural potentials and promises of development and investment by the government in the sector. In the process, it highlights some of the main obstacles that stand in the way and proposes a framework within which the issues could be resolved, making tourism an important contributor to LED.

Sustainable tourism development, local economic development and the Millennium Development Goals

The concept of "sustainable tourism development" has its root in the broader concept of "sustainable development", which can be traced back to the World Commission on Environment and Development Report, named "Our Common Future" (also known as the Brundtland Report) (WCED, 1987). Sustainable development according to the Brundtland Report is defined as "development that meets the needs of the present without compromising the ability of the future generation to meet their own needs" (World Council for Economic Development [WCED], 1987: 43). The core values of this report, which has been criticized for providing limited practical guidance on how to put its ideas into operation, where poverty alleviation, the achievement of longterm equity and ecological well-being of humanity (WCED, 1987). Other international conferences/ charters espoused and expanded these concepts and attempted to provide frameworks for the implementation of sustainable development principles. Examples include the 1992 United Nations Conference on Environment and Development (also known as the Rio Earth Summit) which came up with the Agenda 21, the UN Millennium Declaration (2000) which gave birth to the Millennium Development Goals (Miller \& Twining-Ward, 2005). The importance of tourism to sustainable development has been addressed by the United Nations (UN) and its agencies on numerous occasions. In 1995, a United $\mathrm{Na}^{-}$ tions Charter for Responsible Tourism was adopted in Lanzarote, while the UN General Assembly during its 1997 special session to review the implementation of Agenda 21 noted the importance of tourism and requested the development of an action plan specific to tourism development. This was followed by the 2002 World Summit on Sustainable Development in Johannesburg (South Africa), where the importance of tourism to sustainable development 
was further stressed, culminating with the Bali Declaration on Sustainable Tourism Development (2005) which further emphasised the need to facilitate, promote and encourage tourism development and management in a responsible manner (WTO, 2002; unescap.org, 2005).

However, before all these declarations and calls for action, tourism in the 1950s and 1960s was viewed as a 'smokeless industry' because its negative impacts were thought to be benign while its economic, socio-cultural and environmental contributions to LED and wellbeing of host communities (most of which were located in developing countries) were considered as overwhelming. In the early 1970s however, negative environmental, economic and socio-cultural impacts started appearing especially with the growth of the mass tourism phenomenon (Hall \& Page, 2006). Tourism researchers and planners from then on began proposing alternative methods of developing the industry. Consequently, in the early 1980 s and 1990 s, terms such as responsible, ethical, pro-poor, culture/heritage, alternative as well as sustainable tourism were used to define this new form of tourism (Frey \& George, 2010). Sustainable tourism has however become the most widely used of all these terms. That notwithstanding, there is still a lot of controversy surrounding its definition and how it can be successfully implemented (Butler, 1991; Hunter, 1995; Miller \& Twining-Ward, 2005). This controversy is because some arguments have been advanced that sustainable tourism should be concerned in creating conducive environments and situations where tourism flourishes as an end in itself like an economic activity, i.e. environmentally sustainable tourism (Muller, 1994; Cater \& Goodall, 1992). Other researchers however maintain that sustainable tourism theories, practices and policies should be directed at finding a role for tourism in which it becomes part of a more holistic concept covering the general framework/concepts of sustainable development from which the whole concept itself evolved in the early 1990s (Hunter; 1997; Hunter, 1995; Collins, 1999; Butler, 1996).

Butler (1999) points out that the contention mainly comes from the use of the word "sustainable" and its interpretation as well as application to a variety of activities within the tourism context especially in terms of scale, scope, sectoral context, timescale and (extra) parochiality. Consequently, though many definitions of sustainable tourism have been advanced, Butler's (1993) definition stands out as one of the main definitions which clearly posits sus- tainable tourism as a tool that enhances sustainable development and consequently local economic development. To him, sustainable tourism is:

"...tourism which is developed and maintained in an area in such a manner and at such a scale that it remains viable over an indefinite period and does not degrade or alter the environment (human and physical) in which it exists to such a degree that it prohibits the successful development and well-being of other activities and processes"(Butler, 1993: 29).

Sustainable tourism is seen here as a tool that contributes to the improvement of the quality of life of the hosts, while at the same time meeting demands of the tourism industry and the tourists themselves as well as protecting natural resources and the environment. This perspective is in line with the World Tourism Organization's 1998 definition of sustainable tourism development which is frequently used by tourism planners and in tourism research literature. It states that:

"Sustainable tourism development meets the needs of the present tourists and host regions while protecting and enhancing opportunities for the future. It is envisaged as leading to management of all resources in such a way that economic, social, and aesthetic needs can be fulfilled while maintaining cultural integrity, essential ecology processes, biological diversity, and life support systems"(WTO, 1998: 21).

Both definitions clearly points out that in order for the sustainable development of tourism to be successful, sound management of environmental, social and cultural resources which guarantee the satisfaction to all stakeholders and ensure the protection and conservation of these resources for the present and future generations is imperative. If this is effectively done, it will be possible to attain MDG7 (environmental sustainability). In addition, tourism's localization (local culture and/or nature) and the need for active and profitable community engagement as well as proper management and integration of tourism into other economic activities of the community/region is emphasized (Hunter, 1997; $\mathrm{McCool} \&$ Moisey, 2001). It is only through these actions that tourism could become an important contributor to local economic development and in so doing attaining MDG1 (extreme poverty eradication).

The main purpose of local economic development is to "build up the economic capacity of a local area to improve its economic future and the quality of life for all" (World Bank, undated). In LED (which is not geographically scale-bound), active stakehold- 
er participation (which is also a key characteristic of STD) is imperative. The consultation, inclusion and participation of all stakeholders/partners in all stages from planning through decision making, implementation and management offers local government, the private, business, non-governmental and non-profit sectors, and local communities/areas the opportunity to work together to improve the local economy thereby enhancing their economic and destination competitiveness and sustainability (Helmsing, 2005; World Bank, 2003). LED is thus primarily concerned with the ability of communities to devise ways and means of continually improving their investment climate and providing enabling business environments, thereby enhancing their competitiveness and ability to retain jobs, create employment opportunities and improve incomes and therefore economic growth. One of the means of enhancing this competiveness and maintaining economic growth is through the sustainable development of tourism in regions which are blessed with natural and cultural attractions. Broadly speaking, LED strategy has gone through three different phases or waves of development since the 1960s. These are the traditional approach (1960s to early 1980s), the capacity building strategy (mid 1980s to 1990s) and the development of the information flows phase (from the 1990s to the present) (World Bank, undated). A good number of efficient and effective initiatives are necessary or need to be adopted in order for the local communities to be able to meet and respond to the demands of LED programmes which have no single implementation model or approach. These include physical planning, economics and marketing, in addition to incorporating many local government and private sector functions such as environmental planning, business development, infrastructure provision, real estate development, finance, good governance and accountability, equitable and active stakeholder participation and ownership (Rodriguez-Pose \& Tijmstra, 2007); initiatives which as earlier discussed are also a prerequisite for the sustainable development of tourism in any destination. LED thus entails the creation or setting up of conditions that promote the stimulation of new opportunities in both rural and urban regions with limited opportunities for economic growth. Tourism is one of those opportunities which can be developed in some regions of Cameroon that are endowed with cultural and natural attractions. If successfully executed and implemented, LED could lead to extreme poverty alleviation and en- vironmental sustainability among others. However LED in SSA has been plagued by a number of issues and has undergone a series of transformations during the last four decades.

\section{Local economic development in sub-Saharan Africa}

There are a good number of poverty alleviation strategies in sub-Saharan Africa all linked to LED. Self-reliance, survival and poverty alleviation rather than finding and creating niche markets, local economy strengthening and increasing competitiveness are some of the key focal points of the majority of LED projects in the region (Binns \& Nel, 1999). The social aspects often take precedence over the economic aspects with all strategies being drawn up by local governments often without consultation of the local business communities and other stakeholders. As a result, most of these strategies do not generate the expected results in terms of economic growth and job creation (Rodriguez-Pose \& Tijmstra, 2007; Hinderson, 2003). During the last two decades however, changes in the political economy of many countries have significantly altered conditions for LED in sub-Saharan Africa. Decentralisation, democratic pluralism and economic liberalisation as well as advances in information and communication technologies (ICT) and managerial changes have significantly brought the world closer (Rogerson \& Rogerson, 2010; Helmsing, 2003; Helmsing, 2005). Decentralisation has led many communities to actually assume responsibility for their own development. In many countries, this has led to the creation of partnerships between the local communities and other stakeholders (both national and international) to ensure better management of the community's natural, physical and human resources thereby stimulating the economy and creating jobs within these communities (Rogerson \& Rogerson, 2010; Helmsing, 2001; Helmsing, 2005). Helmsing (2003) distinguishes three categories of LED initiatives in SSA and these all have a direct bearing on the sustainable development of tourism in the region.

The first are community economic development initiatives which can be applied to both rural and urban settings with slight alterations. These initiatives seek to stimulate and diversify the economic activities of the households by introducing new income generating activities (some of which are related to the tourism industry), promote a sense of community, self-help and empowerment, contrib- 
ute to the generation of self-employment, improve living and working conditions in the communities and create public and community services, thereby reducing their overdependence and dependence on one activity alone (Helmsing, 2003). If successfully applied, they could lead to improvement of livelihoods as well as a reduction in poverty and vulnerability. This is very important in Africa where rapid population growth, less dependence on agriculture, mismanagement and urban migration has not only made many households to become vulnerable but it has increased pressure on some communities and localities and led to an increase in urban poverty (Helmsing \& Egziabher, 2005).

The second LED initiative involves engaging in activities dealing with the production of products that are appealing and developing the conditions that favour the export of these products and services outside the locality. This export base is often made up of different sectors and they each depend on each other for survival. The more they specialise in their different sectors, the more performant they become and the better services they are able to render, hence becoming more appealing (Helmsing, 2003; Helmsing \& Egziabher, 2005). Just like with all other industries, the tourism industry's growth and appeal does not only depend on the natural and cultural environments, but it also largely depends on the supply and provision of the necessary service infrastructure such as transport, accommodation and food, security, health care and human resources by other industrial sectors to the industry (Kimbu, 2010). However as McCormick (1999) observed, manufacturing clusters in Africa are under-developed when compared to other continents. This is primarily due to the absence of enabling environment (i.e. macro and micro finance, competency/capacity learning platforms, collaborative partnerships and networks) and is a serious obstacle to enterprise development. Helmsing (2005) and Helmsing and Egziabher (2005) note that achieving collaboration and cooperation among the various sectors and stakeholders is a serious problem in many African communities.

The third initiative deals with the development of specialised export bases by local economies. This is reflected in correct planning and realisation of the necessary hard and soft infrastructure and the provision of the necessary social and economic overhead capital that is put in place to serve it (Helmsing, 2003). In order for locality development to be successful, the planning and operationalization has to be participatory, simplified and understandable. In addition, control and monitoring mechanisms and regulations have to be instituted during the physical planning, development and management phases. Infrastructure also has to be developed or upgraded and monitoring mechanisms put in place to ensure regular control, while the necessary socio-economic overhead capital (education, research and training institutions, hospitals, information and communication technologies) has to be created to serve not only the industry but the locality as a whole (Rodriguez-Pose \& Tijmstra, 2007; Helmsing, 2003; Helmsing, 2001). The provision of basic hard and soft infrastructure by the government and their astute management generally serves as a stimulus for private investments in the targeted locality. This makes the destination more competitive and attractive to potential investors and also enhances the life quality of the local residents who also profit from these infrastructure and services. The problem in many sub-Saharan African countries and Cameroon in particular is that, though a good number of potential sites (export bases) for tourism development have been identified by the governments, only very limited physical infrastructure has been constructed making these sites less attractive to potential investors and tourists (Kimbu, 2011). In addition, the necessary socio-economic overhead capital is almost inexistent.

\section{Cameroon overview}

Located between West and Central Africa in the Gulf of Guinea, with English and French as the official languages and just 6.5 hours away from continental Europe, Cameroon, which received 572,728 visitors in 2010, has been described as "all of Africa in one country" due to its topographical, floral, faunal and multicultural diversity (MINTOUR, 2007). Cameroon has a total surface area of $475442 \mathrm{~km}^{2}$ and had a population of about 19.5 million inhabitants in 2009 (BBC, 2010). The country's strategic location has given rise to a vast floral and faunal diversity and density. In fact, Cameroon has one of the highest concentrations of endemic species on the African continent apart from the island of Madagascar and was in this regard classified by the World Bank and the World Wide Fund (WWF) as one of the 13 countries worldwide with the highest amount of biological diversity (Riley \& Riley, 2005; Vivien, 1991).

As of 2005, 14\% of Cameroonian territory was under some form of protection on paper and there 
were plans to increase this amount to $19 \%$ (especially after the World Bank's approval to finance Cameroon's Forest and Environmental Policy Development Program Project in 2006 thereby theoretically complying with the Millennium Development Goal of increased environmental conservation and poverty alleviation (World Bank, 2006)). In 2007, Cameroon had 13 national parks, 3 of which were UNESCO-MAB biosphere reserves and one a UNESCO World Heritage Site; 18 wildlife reserves, 3 wildlife sanctuaries, 16 forest reserves and protected areas, 9 cloud (mountain) forest sites in the country covering a total surface area of about 6496499 hectares (UNESCO, 2008; MINTOUR, 2007). This is in addition to the $402 \mathrm{~km}$ of coastline with pristine beaches near the foot of Mount Cameroon in Limbe (South West Region), at the entrance of the equatorial forest around Kribi and Campo (South Region) and on the island of Manoka in the Littoral Region (MINTOUR, 2007). In addition, the country is blessed with a diversity and multiplicity of customs and traditions manifested in the more than 270 spoken languages, architecture, dressing, music, song and dancing especially in the western and northern regions of Cameroon (Benneh, 2008; Paden \& Soya, 1970).

The eastern, western and southern portions of Cameroon (North West, South West, Littoral, Centre, South and East Regions) are potential havens for ecotourism, mountaineering and hiking, cultural and beach tourism development, while the northern part of Cameroon (Adamaoua, North and Extreme North Regions) is the Mecca for safari adventurers and is the most visited part of the country (Kimbu, 2010). With its rich and abundant cultural and natural diversity, different forms of cultural and environmentally sustainable community benefit naturerelated tourism, mountaineering and hiking, cultural and sun and sea tourism initiatives geared at promoting LED are starting to see the light around some of these parks and sites of interest, and could be developed in the other sites if the necessary planning, management and monitoring tools which would facilitate hard and soft infrastructure development and management were put in place. This adventure and discovery element places Cameroon according to Butler's (1980) tourism area life cycle at the (late) exploration stage, while it is also a favoured destination of Plog's (1974) allocentric travellers and Cohen's (1972) explorers.

\section{Methodology}

The paper adopts a qualitative approach in that the research is underpinned by 21 in-depth semistructured interviews with key tourism industry stakeholders. Using a purposive snowball sampling technique (Mason, 2002), public and private sec- $^{-}$ tor stakeholders were co-opted to participate in the research. In-depth semi-structured interviews and discussions were used for this research because it allows "...the interviewer to ask certain, major questions the same way each time but is free to alter the sequence and to probe for more information" (Fielding, 1993: 136). Interviews/discussions lasting between 45 minutes to 1.5 hours were conducted with officials from Cameroon's Ministries of Tourism, Forestry and Fauna, and the Ministry of Environment and Nature Protection (6), tour/hotel operators and travel agents (7), representatives of local communities (4), and officials working with NGOs (4) dealing with environmental protection and sustainable tourism development in Cameroon. In addition 6 field trips to potential and existing tourism development sites in the country were undertaken between the months of January and April 2009. Working from a set of prepared guidelines, probing but non directive questions requesting clarification, specification and examples wherever need arose were asked by the researcher to the respondents. The lack of up-to-date secondary data sources and the interviewing strategy adopted meant that the researcher was able to elicit as much information as possible from the respondents about the topic of research, and the following results were generated after a thematic content analysis of the interviews.

\section{Findings and discussion}

In spite of possessing the natural elements favouring the development of an ecologically sustainable nature tourism industry that could lead to poverty alleviation and environmental sustainability, and in spite of the Cameroon government's stated commitment to prioritise the development of the industry as one of the means of stimulating LED in areas devoid of other mineral resources and industries, analysis of the interviews with all stakeholders in Cameroon's tourism sector as well as from field observations revealed that it will be very difficult for countries in the Central African sub-region and Cameroon in particular to attain MDGs 1 $\& 7$ by 2015 . This was mainly due to the existence of some core challenges which made LED through tourism a far fetched reality. These challenges resulted mainly from the lack of simultaneous complementary investments as well as support ser- 
vices and infrastructure in the tourism sector and in other economic sectors by other economic agents (Helmsing, 2003). Principal challenges included the lack of finance leading to the non implementation of management plans, shortage of qualified human capital and inefficient service infrastructure, non implementation of a general tourism policy framework, conflicts of interest between various stakeholders and government policies, as well as nonprofessionalization of the tourism sector.

\section{Lack of capital for investment and expansion}

The lack of finance for macro and micro investments, infrastructural development and management was considered by all interviewees to be a serious handicap. This was the result of little government support to the sector especially after the economic crisis and subsequent market liberalisation and introduction of structural adjustment programs in the mid 1990s whose impacts were still being felt. The lack of capital was also caused by the decline in foreign direct investments (FDI) in Cameroon since the early 1990s notwithstanding the fact that between the years 1980 and 2000, global FDI grew more than 20 times from 67 billion to 1271 trillion (Hemlsing, 2003). However Africa received only a tiny fraction of this FDI and its share actually dropped from $2.8 \%$ in the 1980 s to $0.6 \%$ in the year 2000 , with countries such as Kenya and South Africa profiting most (UNCTAD, 1999). Consequently many potential attractions in Cameroon lacked the basic hard and soft infrastructure and services to accommodate and cater for tourists' needs (Kimbu, 2011).

\section{Absence of a tourism policy and non implementa- tion of a general tourism development framework}

Tourism development almost always involves a greatly expanded role of the state in developing hard and soft infrastructure, drafting and implementing a tourism policy and strategy (dealing with issues such as land use policies, training and employment, visa policy, foreign exchange requirements and import regulations, etc) after consultation with other stakeholders (Jenkins \& Henry, 1982; Wood, 1980). Tourism policy therefore provides the guidelines and the reference points against which any developments in the sector should be evaluated (Dieke, 2006). That notwithstanding, Cameroon's tourism industry had no clear and concise development and management plan and policy nor a National Tourism Office to oversee its development and management. Though a few attempts had in the past been made to come up with policy documents and strategic frameworks they were never implemented, partly due to lack of finance, partly because they were over-ambitious and partly because they were contextually not applicable, having been drawn up by persons (foreign consultants) not well versed with the realities of Cameroon. Examples include the Tourism Sectoral Development Plan drawn up in 2005 which outlined some of the potential sites and types of tourism that had to be developed/consolidated (MINTOUR, 2007), the 2002 Tourism Marketing Plan and the 2008 Destination Branding Report, which respectively outlined strategies for marketing and branding the country as a tourism destination (EMG, 2008; Expansion Strategies Inc., 2002). The absence of a national tourism policy and tourism development strategy has led to the industry being in a disorganised state, with very little cooperation and coordination between various branches of the industry and other sectors of the economy, leading to conflicts of interest among the industry's stakeholders.

\section{Conflicting government policies and stakeholder in- terests}

Actively involving all persons affected by proposed development and subsequent management is the underlying premise of stakeholder theory pioneered by Freeman in 1984. However, conflicting interests between stakeholders involved in community development is a key challenge to LED (Helmsing, 2005; 2001). This was very evident in $\mathrm{Cam}^{-}$ eroon where persistent conflicts of interest between the various ministerial departments as well as between public and private sector stakeholders were partly responsible for the underdevelopment of a sustainable tourism industry in the country. This significantly retarded developments in the industry and its contribution to LED. That notwithstanding, cooperation and collaboration as well as integration and active participation are major issues that have to be seriously considered and addressed in any models that deal with the role of stakeholders in tourism planning, development and management (Hall, 2000; Tosun, 2000; Bramwell \& Sharman, 1999).

In spite of the apparent democratisation and decentralisation measures instituted by countries in the Central African sub-region in the last two decades, research revealed that in practice, governance is still to a large extent centrally planned and administered with very limited consultation and often passive participation of the other stakeholders par- 
ticularly the communities concerned. This confirms Rodriguez-Pose \& Tijmstra, (2007) and Hinderson's (2003) observations about the lack of consultation and non-involvement of all stakeholders in LED initiatives including tourism development and management. Due to the ever changing developmental plans of the government, decisions are sometimes made which stand in direct contradiction to the MDGs of poverty alleviation and environmental sustainability. 'Strategic national interests' often supersede environmental concerns in national parks and protected areas in spite of protests from national and international NGOs. Examples include exploration and eventual exploitation of minerals such as diamonds, gold, bauxite, nickel and cobalt within parts of the bio-diversity rich Boumba-Bek and Lobéké National Parks and the Kribi deep sea port and gas terminal construction project in the Eastern and Southern Regions of Cameroon respectively. In the latter, the government and local inhabitants opted for the construction of the above infrastructure instead of the creation of a marine park citing the economic advantages which could accrue from the realisation of this project in the region over environmental concerns (Bainkong, 2009). Other examples include the proposed construction of the Lom Pangar and the Mve-Ele hydroelectric power plants/ dams in the Eastern and Southern Regions of Cameroon respectively which will not only flood about $318 \mathrm{~km}^{2}$ of the Deng Deng Forest Reserve (one of the rare hardwood forests in Africa) which was spared destruction during the construction of the World Bank sponsored Chad-Cameroon pipeline in 2003, but will also submerge parts of the biodiversity-rich Lom Pangar Reserve (Horta, 2010; Ngala, 2009). These are all natural parks with huge potentials for the development of nature-related tourism activities which will be destroyed. These projects according to officials of WWF Cameroon will have serious negative socio-cultural and environmental consequences because whole communities will be displaced and the biodiversity found within these parks which risk being decimated. That notwithstanding, it is expected that electricity output will be boosted after the completion of these power plants and there will be an increase in economic activities when the commercial exploitation of minerals commences (Elvido, 2009). Conflicting stakeholder interests coupled with prioritising immediate short-term economic national benefits meant that important environmental conservation and biodiversity protection measures taken into consideration when drawing up management plans often end up being shelved or only partially implemented.

\section{Non-implementation of management plans}

Five year renewable management plans were introduced in all of Cameroon's main national parks as from the mid 1990s. However, the effective implementation of these plans which clearly call for the integration and profitable participation of local communities in park management and conservation as well as the development of environmentally friendly sustainable tourism activities that promote LED in and around these parks as one of the means to reduce pressure on the parks' biodiversity leaves much to be desired. This is partly due to the inefficiency of most governments in sub-Saharan Africa in general and Cameroon in particular where government effectiveness was estimated at just around $30 \%$ in 2004 (Nelson, 2008; Kaufman et al., 2005; World Bank, 2004). Any biodiversity conservation and ecotourism development projects near or within parks is mostly realised thanks to the technical and financial assistance of international non-governmental organisations. Examples include the World Wide Fund for Nature (WWF) and the UK Department for International Development (UKDFID) sponsored Korup Project (1997-2002) in the Korup National Park, the UKDFID - World Bank Global Environmental Facility (GEF) - German Agency for Technical Cooperation (GTZ) funded Mount Cameroon Project (1994 - 2002) and the German Development Organisation (DED) - GTZ funded ecotourism project of the Mount Cameroon Inter Communal Ecotourism Organisation (1997-2005). In these projects, local communities were to be actively and profitably engaged in conservation work in these parks by being trained in alternative income generating activities centred on conservation and eco- $^{-}$ tourism (Mount-cameroon.org, 2007; LBZG/MCBCC, 2002). During their duration, former hunters and forest product gatherers from the surrounding communities were retrained in sustainable farming techniques; some were trained and employed to work as guides, porters, home-stay providers. Until the departure of the foreign partners which was often accompanied by a freeze in foreign funding, the projects were very successful in biodiversity conservation, poverty alleviation and stimulating LED in the communities where they were based. In the various communities for example, special accounts were created in which a percentage of revenue generated from tourism activities was deposited and 
used in carrying out developmental projects such as electrification and potable water provision in the villages involved. Thereafter, financial and managerial deficiencies set in, and a good number of villagers who had been gainfully employed in the different projects reverted to their past preoccupations of illegal forest product harvesting and poaching. In addition, maintenance of the infrastructure on these sites virtually came to a standstill, and most are currently in a state of disrepair leading to a corresponding decrease in visitor numbers which had been steadily increasing during these projects. Thus even though the government's stated commitment includes the sustainable development of eco/nature tourism activities around most of Cameroon's nature parks and reserves, this is in practice hampered by the desire to commit adequate and scarce financial resources to achieve these goals. Without external help from foreign donors as is presently the case with the WWF sponsored Kudo-Zombo Project in the Campo-Ma'an National Park, most of these plans and proposed ecotourism ventures will never executed (Lukong, 2008).

\section{Deficiencies in human capital management}

Environmental sustainability and conservation can only be achieved with the right calibre of service personnel needed to carry out tasks related to conservation. Unfortunately this is not the case with most of Cameroon's parks and reserves. Just like in most countries of sub-Saharan Africa, the poor state of higher education both in physical infrastructure and human resources has led to a scarcity of qualified workers to work in the industry (RodriguezPose \& Tijmstra, 2007; Helmsing, 2003). The presence of only two professional schools in the country for the training of senior forestry and wildlife engineers and mid-level forestry technicians and only a handful of institutions specialised in hospitality and tourism management means that there is a shortage of well trained and skilled professional staff needed to oversee and carry out day to day management, not only in the natural parks and sites but also in other sectors of the tourism and hospitality industry as a whole in the country. In the Korup National Park for example there were only 3 mid-level technicians and 20 ecoguards responsible for patrolling and ecological monitoring. This was lesser than the number stipulated in the Park Management Plan (which provided for 36 ecoguards) and when the IUCN ratio of ecoguards to park surface area was taken into consideration. It was the same situation in all the other parks and reserves in the country. As a result, parks such as the Dja Faunal Reserve, Banyang-Mbo sanctuary and the Faro National Park which was home to a large variety of threatened species such as black rhinoceroses, elephants and cheetahs were over-poached by poachers mostly from the neighbouring Central African Republic and Chad and illegal lumber harvesting was carried out by companies which had concessions near these parks (Nchandji, 2006; Nyang, M. \& Hamerlynck, 2006; MacAllister, 2005; Riley \& Riley, 2005). In addition, the remoteness of most of these parks, coupled with low public sector wages in general and in the tourism industry in particular in sub-Saharan Africa and Cameroon, also acted as a disincentive and made it difficult for the industry to attract and retain qualified staff willing to work in these parks (The Commission for Africa, 2005; Helmsing, 2002).

It is as a result of these deficiencies that in the 2009 Travel and Tourism Competiveness Report, Cameroon was classed a lowly $94^{\text {th }}$ in terms of the availability of local research and training facilities and $104^{\text {th }}$ in terms of the extent staff training in the tourism sector out of 133 countries. A lot of improvements need to be done in this sector for it to be competitive (Blanke \& Chiesa, 2009). Tourism development that contributes to the reduction of extreme poverty, promotes environmental sustainability and ultimately plays a strategic role in LED in $\mathrm{Cam}^{-}$ eroon can be successfully developed if complementary investments take place in other related sectors of the chain both upstream and downstream.

Contribution: Towards the implementation of a sustainable tourism approach that guarantees local economic development

The absence of an effective tourism framework coupled with the lack of finance for the development and promotion of all other aspects of the industry relegates tourism in Cameroon to a secondary activity. Many private agents engaged in the sector consider it as an addendum to their other business interests. A similar scenario plays out in the local communities where those employed consider the sector as not being sustainable enough for them to engage in it full time. Thus when ecotourism ventures are initiated in most communities (Mount Cameroon Region, Korup National Park or Belo Rural Development Project for example), the amount of enthusiasm shown by the locals is always very low. The benefits of the training courses offered to villagers which often accompany the introduction of these projects are often 
short-lived because when participants trained in various capacities (as guides, porters, ecoguards) realise that the proceeds from tourism are neither immediate nor regular, depending largely on the tourist season (November to April) and visitor numbers, the general tendency is for them go back to their past preoccupations which are often unsustainable and have negative environmentally consequences. Consequently, in comparison to countries such as Botswana, Kenya or Senegal where up to $6 \%$ of the labour force is employed in the travel and tourism industry, which itself contributed more than $6 \%$ to the GDP of these countries in 2008, in Cameroon the WTTC estimates show that only $1.3 \%$ of total employment was generated from direct tourism industry jobs and $3.5 \%$ of total national employment was generated by the travel and tourism economy as a whole. In addition, the travel and tourism industry in Cameroon was expected to contribute only $2.9 \%$ to the GDP during this same period (Blanke \& Chiesa, 2008).

In order to guarantee the effective utilisation of Cameroon's tourism potential as one of the key tools for attaining the MDGs of poverty alleviation and environmental sustainability and in so doing LED, tourism would first and foremost have to be recognised as being on a par with other industrial sectors in Cameroon with the capacity to generate revenue and contribute to the GDP, create jobs and improve standards of living. If this reality is recognised and accepted by the government, the Ministry of Tourism and related ministries will have to be provided with a budget enabling them to put in place the necessary hard and soft infrastructure which will facilitate the effective development and management of the country's tourism industry (Dieke, 2006; Wood, 1980). This is however not the case presently. Figure 1 is a proposed integrated framework which will facilitate LED and the attainment of the MDGs of poverty alleviation and environmental sustainability through the development of a sustainable nature-based tourism industry in Cameroon.

The double-sided arrows in Figure 1 clearly indicate that in order to successfully introduce tourism to the communities as a tool for local economic development, poverty alleviation and environmental protection in Cameroon, various inter-relating factors will have to be taken into consideration when developing a tourism strategy. The first major task would involve the development of a tourism strategy which would clearly define the mission, goals and objectives of tourism development in the coun- try, region and communities. Identifying and inventorying all existing and potential development sites and stakeholders, the challenges inherent in their development and the development of management plans will also be another key element in this strategy. It is only after this that it will be possible to have a clear picture of the industry and development facilitated.

Another important chore in the development process will be for the government and committed private sector stakeholders and non-governmental organisations to carry out education and sensitisation campaigns throughout the country and most especially in areas of existing and potential tourism development sites. The inhabitants will have to be sensitised and educated on the benefits that the sustainable development and management of tourism resources can bring to their communities, as well as made aware of the fact that tourism development is a continuous process requiring constant monitoring and its rewards are not often immediate.

Just as with any LED projects, local communities, as Helmsing (2003) and Helmsing (2005) remarked, have to be empowered and given the freedom to control and manage the tourism projects. Empowerment will come through decentralisation which Rogerson and Rogerson, (2010) and (Helmsing, 2001) observed often leads to better management of a community's resources and projects. Successful management and monitoring of these projects can only be guaranteed after they must have received initial training through capacity building workshops and institutions set up by the government in conjunction with other stakeholders with the necessary expertise and know-how. Without the necessary training, the community members will not be able to manage these structures properly. Proper management and regular monitoring will lead to tourism being developed in a sustainable manner and the attainment of MDGs 1 and 7 (Figure 1).

Another factor to be taken into consideration will be that of active stakeholder collaboration and cooperation, which is essential to the success of LED projects. This, according to Helmsing (2005) and Helmsing \& Egziabher (2005), was a critical stumbling block for many LED initiatives in SSA. All tourism industry stakeholders will have to effectively work together in the development of the industry, which would have to be placed under the supervision of an autonomous national, regional and local tourism boards (bringing together representatives of public 


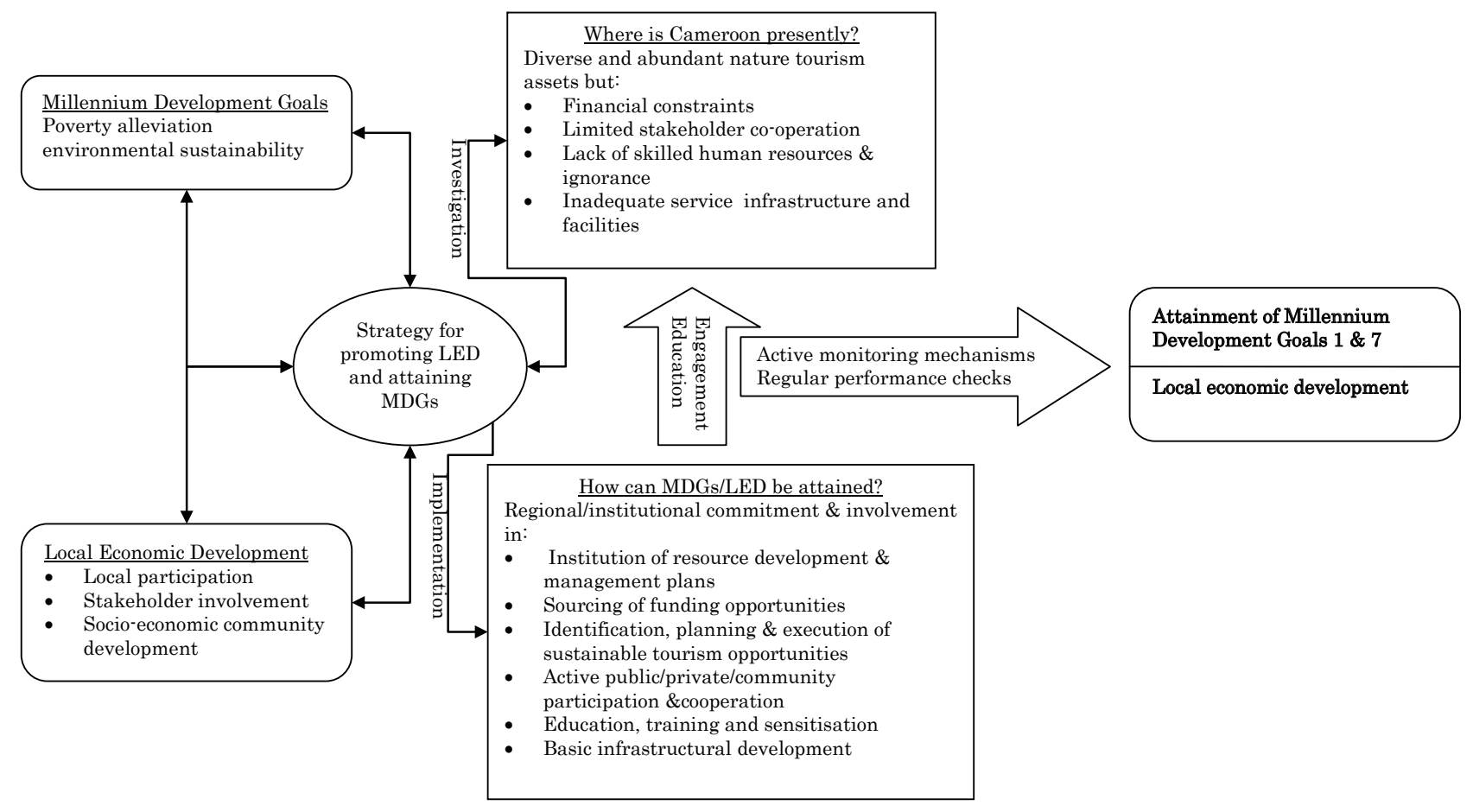

Figure 1. Framework for the Attainment of Millennium Development Goals (1 \& 7) and LED through Sustainable Tourism Development in Cameroon

and private sector stakeholders) that will have to be created. One of the initial tasks of this board will be to come up with a practical and financially sustainable framework for tourism development and management in the country, as well as to assume responsibility for the professionalization of the industry. It is this framework that will clearly outline the direction of tourism's development and the steps that will have to be overcome in order to achieve the sustainability the industry's development.

The government on its part, in addition to creating the basic enabling infrastructure necessary for tourism development in the country which, as Rodriguez-Pose \& Tijmstra (2007), Helmsing, (2003) and Helmsing (2001) noted will not only serve the industry but the locality as a whole, will also have to liberalise the sector and reduce the administrative bottlenecks as well as give tax incentives to potential investors. These measures will not only stimulate local investments by local private sector individuals but could also attract foreign direct investments from international investors who up till now have shied away from undertaking any serious developments in the country because of the general absence of a conducive environment for tourism development.

In addition, the government should engage in a serious and continuous marketing campaign in the potential source markets of Europe and North America where very little has been done up till now as regards marketing and promotion. This marketing could take place in the form tourism trade fair attendances in reputed fairs of Berlin, Paris and London for example.

\section{Conclusion}

The spatial location of the country, the rich and varied topographical, floral and faunal biodiversity and as well as the multi-linguistic and cultural diversity of the country provide the primary components necessary in making Cameroon a very fertile terrain for the development of a sustainable tourism industry capable of significantly contributing to the realisation of the Millennium Development Goals of poverty alleviation and environmental sustainability. However a lot of work still has to be done with regards to coordinating and providing the nec- 
essary services and infrastructures which will harness these potentials and make them profitable to all stakeholders engaged, and which will guarantee that future generations still get to profit from them. It is only when this foundation has been laid and constant monitoring ensured that it will be possible to look positively into the future and be certain that tourism will be a significant arsenal in the fight against poverty and environmental sustainability in Cameroon.

\section{References}

Bainkong, G.

2009 Kribi deep seaport: Construction begins next year. Available at: http://www.camerounlink.net/ fr/news.php? [Retrieved August 24, 2010].

Benneh, G. (Ed.)

2008 Cameroon: Encyclopaedia Britannica. Available at: http://www.britannica.com/eb/article-9110775/Cameroon [Retrieved November 19, 2010].

Blanke, J. \& Chiesa T. (Eds.)

2009 The Travel and Tourism Competitiveness Report 2009: Managing in a time of turbulence. Davos: World Economic Forum.

Blanke, J. and Chiesa T. (Eds.)

2008 The travel and tourism competitiveness report 2008: Balancing economic development and environmental sustainability. Davos: World Economic Forum.

Bins, T. and Nel, E.

1999 "Beyond the development impasse: The role of local economic development and community self-reliance in rural South Africa". The Journal of Modern African Studies, 37: 389-408.

Botswana Tourism Board

2007 Botswana ecotourism best practices manual. Available at: http://www.botswanatourism.co.bw/ doc/ecotourism_manual.pdf [Retrieved November 22, 2010].

Bramwell, B. and Sharman, A.

1999 "Collaboration in local tourism policy making." Annals of Tourism Research, 26: 392-415.

British Broadcasting Corporation (BBC)

2010 Country Profile: Cameroon. Available at: http://news.bbc.co.uk/2/hi/africa /country_profiles/1042937.stm [Retrieved November 10, 2010] Butler, R.

1980 "The concept of the tourism area cycle of evolution". Canadian Geographer, 24: 4.

Butler, R.

1991 "Tourism, environment and sustainable de- velopment." Environmental Conservation, 18: 201-209.

Butler, R.W.

1993 "Tourism - An evolutionary approach." In: Nelson, J.G., Butler, R.W. \& Wall, G. (Eds.), Tourism and Sustainable Development: Monitoring, Planning, Management (pp.27-44). Waterloo: University of Waterloo.

Butler, R.

1996 "Problems and possibilities of sustainable tourism: The case of the Shetland Islands." In: Briguglio, L. Butler, R., Harrison, D. \& Filho, W.L. (Eds.), Sustainable Tourism in Islands and Small States: Case Studies (pp. 11-31). London: Pinter.

Butler, R.W.

1999 "Sustainable tourism: A state-of-the- art review." Tourism Geographies, 1(1): 7-25.

Cohen E.

1972 "Towards a sociology of international tourism." Social Research, 39: 164-182.

Cater, E. and Goodall, B.

1992 "Must tourism destroy its resource base?" In: France, L. (Ed.), The Earthscan Reader in Sustainable Tourism (pp. 85-89). London: Earthscan Publications.

Collins, A.

1999 "Tourism development and natural capital." Annals of Tourism Research, 26(1): 98-109.

Dieke, P. U. C.

2006 Developing tourism in Africa: Issues for policy consideration. Available at: tradeinservices. mofcom.gov.cn. [Retrieved November 03, 2010].

Elvido, S. C.

2009 Biodiversité: L'exploitation minière menace les aires protégées. Available at: http://www.camerounlink.net/fr/ news.php? [Retrieved August 26, 2010].

Emerging Markets Group

2008 Cameroon tourism destination branding: Final report. London: Emerging Markets Group Ltd.

Expansion Strategies Inc.

2002 Cameroon tourism marketing plan, Montreal: Expansion Strategies Inc.

Fielding, N.

1993 "Qualitative interviewing". In Gilbert N. (Ed.), Researching Social Life (pp.135-53). London: Sage.

Freeman, R. E.

1984 Strategic management: A stakeholder approach. Boston: Pitman.

Frey N and George, R.

2010 "Responsible tourism management: The missing link between business owners' attitudes 
and behaviour in the Cape Town tourism industry." Tourism Management, 31(5): 621-628.

Gabontour

2010 Gabon a world of natural wonders: National Tourism Office of Gabon. Available at: http:// www.legabon.org/flash/gabontour/gabontour.php [retrieved: February 02, 2011]

Hall, C. M.

2000 Tourism planning processes and relationships. Harlow: Prentice Hall.

Hall, C.M. and Page, S.J

2006 The Geography of Tourism and Recreation: Environment, Space and Place. London: Routledge.

Helmsing, A. H. J.

2001 "Externalities, learning and governance: Perspectives on local economic development". Development and Change, 32(2): 377-208.

Helmsing, A. H. J.

2002 "Decentralisation, enablement, and local governance in low income countries". Environment and Planning C: Government and Policy 20: 317-340.

Helmsing, A. H. J.

2003 "Local economic development: new generations of actors, policies and instruments for Africa”. Public Administration and Development 23: 67-76.

Helmsing, A. H. J.

2005 "Governance of local economic development in sub-Saharan Africa: Who are the dancers and do they act 'in concert'?" In T. G. Egziabher \& A. H. J. Helmsing (Eds.), Local economic development in Africa: Enterprises, communities and local development (pp. 300-331). Maastricht: Shaker Publishing BV.

Helmsing, A. H. J and Egziabher, T. G.

2005 "Local economic development in Africa: Introducing the issues". In Egziabher, T.G. \& Helmsing, A. H. J. (Eds.), Local economic development in Africa: Enterprises, communities and local development (pp. 1-17). Maastricht: Shaker Publishing BV.

Hinderson, D.

2003 "Connecting economic growth with poverty alleviation: South Africa's LED challenge". Hologram, 1(1): 2-7.

Horta, C. (Ed.)

2010 The World Bank Group and the Chad Cameroon Oil \& Pipeline Project. Berlin: Group Chad Hunter, C.

1995 "On the need to reconceptualise sustainable tourism development." Journal of Sustainable Tourism, 3: 155-165.

Hunter, C.

1997 "Sustainable tourism as an adaptive para- digm." Annals of Tourism Research, 24(4): 850867.

Jenkins, C.L. and Henry, B.M.

1982 "Government involvement in tourism in developing countries." Annals of Tourism Research, 9(4): 499-521.

Kaufman, D., Kraay, A. and Mastruzzi, M.

2005 Governance matters, IV: Governance indicators for 1996-2004, WP 2630. Washington DC: World Bank.

Kimbu, A. N.

2010 Sustainable tourism development management in Central Africa: A case study of the tourism industry in Cameroon. Doctoral dissertation, Nottingham Trent University. Nottingham.

Kimbu, A. N.

2011 "The role of transport and accommodation infrastructure in the development of eco/nature tourism in Cameroon". Tourism Analysis, 16(2): 137-156.

LBZG/MCBCC.

2002 Limbe Botanical and Zoological Garden; our history. Online at: http://www.mcbcclimbe. org/history.shtml [Retrieved February 12, 2010]. Lukong, P.N.

2008 "America to support Cameroon's ecotourism”. Cameroon Tribune. Available at: http://allafrica.com/stories/ 200801100728.html [Retrieved November 07, 2010].

MacAllister, M.

2005 Elephants of Cameroon. Waza Anti-Poaching Report. Available at: http://www.fieldtripearth.org/article.xml?id=1189 [Retrieved September 27, 2010].

Mason, J.

2002 Qualitative researching. London: Sage.

McCool S.F. and Moisey, R.N.

2001 Tourism, recreation and sustainability: Linking culture and the environment. Wallingford, Oxon: CABI.

McCormick, D.

1999 "African enterprise clusters and industrialisation: Theory and reality". World Development, 27(9): 1531-1551.

Miller, G. and Twinning-Ward, L.

2005 Monitoring for a Sustainable Tourism Transition: The Challenge of Developing and Using Indicators. Wallingford: CABI Publishing.

Ministry of Tourism (MINTOUR).

2007 Annuaire des statistiques du tourisme. Yaoundé: MINTOUR.

Muller, $\mathrm{H}$.

1994 "The thorny path to sustainable tourism development". Journal of Sustainable Tourism, $2(3): 131-136$ 
Nchandji, A.C.

2006 "Elephants: Poaching weapons and new experience from the Banyang-Mbo Wildlife Sanctuary, Cameroon". Wildlife Justice, 3. Available at: http://www.lagaenforcement.org/ [Retrieved October 02, 2010].

Nelson, J.

2008 Still off of the conservation map in Central Africa: Bureaucratic neglect of forest communities in Cameroon. World Rainforest Movement, Forest Peoples Programme. Retrieved November 27, 2010, from http://www.wrm.org.uy/ countries/Cameroon/still.html

Ngala, K. C.

2009 "Cameroon: Fears for forest as dam construction begins". The Post Online. Available at: http://www.postnewsline. com/2009/08/ [Retrieved November 04, 2010]

Nyang, M. and Hamerlynck, O.

2006 Rapport de suivi de l'état de la conservation de la réserve de faune de Dja en Republique du Cameroun, site de Patrimoine Mondiale. Paris: UNESCO, IUCN.

Paden, J.N. and Soja, E.W.

1970 The African Experience. Evanston: Northwestern University Press.

Plog, S.

1974 "Why destination areas rise and fall in popularity". Cornell Hotel and Restaurant Quarterly, 15: 13-16.

Riley, L. and Riley, W.

2005 Nature's strongholds: The world's great wildlife reserves. Princeton: Princeton University Press.

Rodriguez-Pose, A and Tijmstra, S. A. R.

2007 "Local economic development in sub-Saharan Africa. Environment and Planning C". Government and Policy, 25: 516-36.

Rogerson, C. M. and Rogerson, M. J.

2010 "Local economic development in Africa: Global context and research directions". Development Southern Africa, 27(4): 465 - 480.

The Commission for Africa

2005 Our common interest: Action for a strong and prosperous Africa. London: The Commission for Africa.

Tosun, C.

2000 "Limits to community participation in the tourism development process in developing countries". Tourism Management, 21(6): 613-633.

UNCTAD

1999 World investment report 1999: Foreign Investment and the challenge of development. UNCTAD: Geneva.

\section{UNDP}

2011 United Nations Millennium Declaration. Retrieved August 24, 2011 from, http://www. un.org/millennium/declaration/ares552e.pdf

Unescap.org

2005 Bali declaration on sustainable tourism development. Available at: http://www.unescap. org/ttdw/Publications/TPTS_pubs/Toreview No26_2474/Toreview_No26_ch2.pdf [Retrieved: August 24, 2011].

\section{UNESCO}

2008 The Dja Faunal Reserve. UNESCO. Available at: http://whc.unesco.org/en /list/407/documents/ [Retrieved January 31, 2010].

Vivien, J.

1991 Faune du Cameroun, Guide de mammifères et poisson. Yaoundé: GICAM et Coopération Française.

Wood, R.E.

1980 "International tourism and cultural tourism in South East Asia". Economic Development and Cultural Change, 28 (31): 561-581.

World Bank

2003 Local economic development: quick reference. Washington DC: Urban Development Division, The World Bank.

World Bank

2004 Sustainable Development Reference Guide. Washington DC: World Bank

World Bank

2006 Cameroon: Forest and environment development program. Available at: http://web.worldbank.org/external/projects/main? [Retrieved January 17, 2011].

World Bank

Undated What is Local Economic Development (LED)? Available at: http://web.worldbank.org/ [Retrieved August 24, 2011].

World Commission on Environment and Development (WCED)

1987 Our Common Future. London: Oxford University Press.

World Tourism Organisation (WTO)

1998 Guide for local authorities on developing sustainable tourism. Madrid: World Tourism Organisation.

World Tourism Organisation (WTO)

2002 Statement by Francesco Frangialli, Secretary-General of the World Tourism Organization, at the World Summit on Sustainable Development Johannesburg, South Africa, 29 August 2002. Available at: http://www.un.org/events / wssd/statements/wtoE.htm [Retrieved: August $24,2011]$.

Recibido:

$15 / 02 / 2011$

Reenviado:

$30 / 09 / 2011$

Aceptado:

$31 / 10 / 2011$

Sometido a evaluación por pares anónimos 